Jumal Penditian danEvaluas Penddikan

\title{
MODEL MULTILE VE L PERTUMBUHAN ANAK USIA 0-24 BULAN DAN VARIABEL YANG MEMPENGARUHINYA
}

\author{
IniantonA nitonang \\ Politeknik Kesehatan Kemenkes Y ogyakrta \\ iriantonan@yahoo.co.id
}

\begin{abstract}
Abstrak
Tujuan umum penelitian ini untuk mengkaji bagaimana berbagai variabel mempengaruhi pertumbuhan anak usia 0-24 bulan di kabupaten Sleman. Penelitian noneksperimen desain korelasional ini dilakukan pada 272 anak usia 0-24 bulan yang diambil secara acak stratifikasi dari dua kecamatan (Sleman dan Moyudan) yang ditentukan secara purposif. Analisis multilevel pertumbuhan anak dilakukan dengan program Stata-10 dan analisis jalur dilakukan dengan program Amos-8. Hasil penelitian menunjukkan bahwa ada hubungan variabel berat badan lahir, jenis kelamin dan strata usia anak dan status gizi ibu dengan pertumbuhan anak pada level-1 dan ada hubungan variabel hasil penimbangan pada level-2, sedangkan pada level 3 ada hubungan yang tidak signifikan hasil penimbangan dan pencapaian program. Hasil analisis jalur yang mempengaruhi pertumbuhan anak 0-24 bulan, yakni variabel endogmaus terdiri dari status gizi ibu, pengetahuan ibu tentang gizi seimbang, pertumbuhan anak indeks $\mathrm{BB} / \mathrm{U}$, hasil penimbangan tingkat dusun dan hasil program tingkat desa. Sedangkan variabel exœenas terdiri dari sikap ibu terhadap posyandu, berat badan lahir, jenis kelamin dan stratifikasi usia anak.
\end{abstract}

Kata kunci: Mood multilede, Petumbuhananak 0-24 bulan

130 - Jumal PenditiandanEvaluas Penddikan E disi D ies Natalis ke-48 UNY 


\title{
A MULTILEVEL MODEL FOR THE GROWTH OF CHILDREN AGED 0-24 MONTHS AN D THE VARIABLES AFFECTIN G IT
}

\author{
IniantonA itonang \\ Politeknik Kesehatan Kemenkes Y ogyakrta \\ iriantonan@yahoo.co.id
}

\begin{abstract}
The main objective of this study is to investigate how various variables contribute to the growth of children between 0 24 months old in Sleman Regency. This study was a nonexperimental correlational design which was conducted on 272 children aged 0-24 months, selected using the purposive stratified random sampling technique from 21 hamlets in two districts (Sleman and Moyudan). The multilevel analysis of children's growth of was carried out using the Stata-10 program and the path analysis using the Amos-8 program. The results show that there is a significant correlation among variables of children's birth weight, gender, and age stratification and mothers' nutritional status to children's growth at level 1 , and a correlation to the variable of children's weight at level 2, while at level 3 there is no significant correlation between children's weight and program achievement. The path analysis shows that the variables affecting the growth of children aged 0-24 months are endogenous variables, consisting of mothers' nutritional status, mothers' knowledge on balanced diet, children's growth index, children's weights measured at the hamlet and the result of program at village level, and exogenous variables, consisting of mothers' attitude concerning Posyandu, children's birth weight, gender and age stratification.
\end{abstract}

Keywords: miltiled modd, gouth of dildren ageel 0-24 months 


\section{Pendahuluan}

Gizi berkaitan erat dengan kualitas hidup manusia yang diketahui melalui ukuran Human Devdqpment Index (HD I) atau Indeks Pembangunan Manusia (IPM). Kaitan faktor gizi dengan IPM ditentukan melalui tiga bidang pembangunan, yaitu: (1) bidang kesehatan, gizi menentukan usia harapan hidup penduduk; (2) bidang ekonomi, gizi menentukan produktivitas masyarakat; dan (3) bidang pendidikan, gizi membentuk fisik dan kecerdasan manusia (So ekirman 2000). Rendahnya IPM di Indonesia sangat dipengaruhi oleh rendahnya status gizi dan kesehatan penduduk. Anak yang kekurangan gizi pada usia balita akan tumbuh pendek, dan mengalami gangguan pertumbuhan dan perkembangan otak yang berpengaruh pada rendahnya tingkat kecerdasan, karena tumbuh kembang otak $80 \%$ terjadi pada masa dalam kandungan sampai usia 2 tahun. Indonesia diperkirakan kehilangan 220 juta IQ poin akibat kekurangan gizi. Dampak lain dari keadaan gizi kurang adalah menurunkan produktivitas yang diperkirakan antara 20-30\% (D epkes, 2005).

Hasil penelitian kesehatan dasar di Indonesia (D epkes, 2007:35,3738) menunjukkan kondisi gizi dilihat dari berbagai dimensi: (1) indeks berat badan menurut usia (BB/ U) ditemukan balita dengan status gizi buruk, gizi kurang dan gizi lebih masing-masing 5,4\%, 13\% dan 5,4\%; (2) indeks tinggi badan menurut usia (TB/U) ditemukan balita dengan kategori sangat pendek dan pendek masing-masing 18,8\% dan 18\%; (3) indeks berat badan menurut tinggi badan (BB/ TB) ditemukan balita dengan kategori sangat kurus, kurus dan gemuk masing-masing 6,2\%, 7,4\% dan 12,2\%. Sama halnya dengan kondisi secara nasional, hasil penelitian kesehatan dasar di Propinsi DIY (D epkes, 2007:44-46) adalah: (1) indeks berat badan menurut usia (BB/ U) ditemukan balita dengan status gizi buruk, gizi kurang dan gizi lebih masing-masing 2,5\%, 9,1\% dan 3,8\%; (2) indeks tinggi badan menurut usia (TB/ U) ditemukan balita dengan kategori sangat pendek dan kategori pendek masing-masing 11,5\% dan 16,1\%; (3) indeks berat badan menurut tinggi badan (BB/ TB) ditemukan balita dengan kategori sangat kurus, kurus dan gemuk masing-masing 3,8\%, 5,2\% dan 12,5\%.

Dinas Kesehatan kabupaten Sleman melaporkan bahwa pada tahun 2006 masih ada masalah dalam meningkatkan kesehatan dan pertumbuhan 
anak balita: (1) terdapat 105 (0,86\%) anak dilahirkan dengan berat badan rendah dari 11.878 bayi lahir hidup, (2) kegiatan posyandu melalui penimbangan anak balita temyata hanya mencakup 69,5\% dari 71.813 anak balita yang stagnan setiap tahunnya, (3) anak balita yang naik berat badannya juga masih sekitar $70 \%$ atau sebanyak 35.168 anak, sehingga dapat dikatakan bahwa sebesar 30\% anak balita di daerah tersebut mengalami gangguan pertumbuhan, (4) bahkan masih ditemukan sebanyak 336 anak menderita kekurangan gizi tingkat berat atau grafik pertumbuhannya berada di bawah garis merah pada KMS (Dinkes Sleman,2007:19).

Berdasarkan masalah yang dikemukakan di atas, maka perlu dilakukan penelitian terhadap pertumbuhan anak usia 0-24 bulan dan variabel yang mempengaruhinya. Kajian pertumbuhan anak usia 0-24 bulan dilakukan melalui model multilevel dan analisis jalur. Variabel yang dianggap paling mempengaruhi pertumbuhan anak usia 0-24 bulan pada model level 1, meliputi variabel langsung utama berupa karakteristik individu anak (berat badan lahir, seks dan stratifikasi usia) dan karakteristik ibu (status gizi). Kemudian variabel tidak langsung yang mempengaruhi pertumbuhan anak 0-24 bulan terdiri dari pengetahuan ibu tentang gizi seimbang dan variabel sikap ibu terhadap kegiatan posyandu. Model pada level 2, yakni disamping mencakup model pada level 1 juga dipertimbangkan program posyandu di tingkat dusun. Analisis dilanjutkan ke model level 3, yakni disamping mencakup variabel pada level 1 dan level 2 , juga dipertimbangkan program posyandu pada tingkat desa.

Penelitian ini bertujuan untuk mendapatkan model multilevel pertumbuhan anak usia 0-24 bulan dan variabel yang mempengaruhinya pada level 1 (individu), pada level 2 (dusun) berupa kegiatan posyandu yang meliputi hasil penimbangan atau tren status gizi (N/D), keberhasilan program (N/S) dan partisipasi masyarakat (D/S), dan pada level 3 (desa) berupa hasil penimbangan atau tren status gizi (N/D) dan keberhasilan program (N/ S) di kabupaten Sleman. Tujuan khusus penelitian ini yaitu: (1) mengetahui pengaruh variabel bebas pada level 1: berat badan lahir, seks dan stratifikasi usia anak, status gizi ibu (IMT), pengetahuan ibu tentang gizi seimbang, dan sikap ibu terhadap kegiatan posyandu dan pertumbuhan

Modd Multiledd PetumbuhanAnak - 133 
anak dengan variabel terikat pertumbuhan anak usia 0-24 bulan; (2) mengetahui pengaruh variabel bebas hasil kegiatan posyandu di tingkat dusun pada level 2: proporsi N/D, N/ S dan D/ S bersama variabel bebas level 1 dengan variabel terikat pertumbuhan anak usia 0-24 bulan; (3) mengetahui pengaruh variabel bebas di tingkat desa pada level 3: hasil penimbangan atau tren status gizi (N/D) dan keberhasilan program (N/S) bersama variabel bebas level 2 dengan variabel terikat pertumbuhan anak usia 0-24 bulan.

Pertumbuhan berkaitan dengan masalah perubahan dalam besar, jumlah dan ukuran sel, organ maupun individu. Perkembangan adalah bertambahnya kemampuan dalam struktur dan fungsi tubuh yang lebih kompleks dalam pola yang teratur dan dapat diramalkan sebagai hasil dari proses pematangan. Faktor yang mempengaruhi tumbuh kembang anak secara umum adalah faktor genetik dan faktor lingkungan. Faktor lingkungan terdiri dari lingkungan prenatal dan lingkungan postnatal. Lingkungan prenatal salah satunya adalah faktor gizi ibu pada waktu hamil, sedangkan lingkungan postnatal antara lain asupan gizi yang diperoleh anak dan faktor psikososial (Soetiiningsih,1995:2-9).

Pemantauan pertumbuhan merupakan suatu rangkaian kegiatan yang terdiri dari pengukuran pertumbuhan fisik dan perkembangan individu di masyarakat dengan tujuan meningkatkan status kesehatan anak, perkembangan dan kualitas hidup. Prinsip dasar penilaian pertumbuhan anak mencakup mengukur berat dan panjang atau tinggi anak dan membandingkan dengan standar pertumbuhan. Sedangkan tujuan penilaian pertumbuhan adalah menentukan apakah anak tumbuh secara normal, atau mempunyai masalah pertumbuhan, atau ada kecenderungan mempunyai masalah pertumbuhan yang perlu ditangani (WHO \& Depkes, 2008:1). Pemantauan pertumbuhan terdiri dari empat kegiatan utama (G riffiths, M., Dickin, K., \& Favin, M.,1996): (1) penilaian (assessment) pertumbuhan anak secara teratur yang terdiri dari penimbangan setiap bulan, pengisian ke kartu menuju sehat (KMS) anak, dan menentukan status pertumbuhan berdasarkan kenaikan berat badan; (2) menindaklanjuti setiap kasus gangguan pertumbuhan berupa konseling dan rujukan; (3) menindaklanjuti berupa kebijakan dan program di tingkat masyarakat, serta meningkatkan

134 - Jumal PenditiandanEvaluasi Penddikan E disi D ies Natalis ke-48 UNY 
motivasi untuk memberdayakan keluarga; (4) melakukan pemantauan, evaluasi serta tindak lanjut.

WHO telah mengembangkan standar pertumbuhan berasal dari sampel anak-anak dari enam negara yaitu Brazil, G hana, India, Norwegia, O man dan Amarika Serikat yang dikenal dengan WHO MilticantreGrouth Reference Study atau MGRS (De Onis M., et al. (2004). MGRS dirancang untuk menyediakan data yang menggambarkan bagaimana anak-anak harus tumbuh dengan catatan memenuhi kriteria tertentu. Penelitian tersebut mengikuti bayi normal dari lahir sampai usia 2 tahun dengan pengukuran yang sering pada minggu pertama. Kelompok anak-anak lain yang berusia 18-71 bulan diukur satu kali, dan selanjutnya data dari kedua kelompok tersebut disatukan untuk menciptakan standar pertumbuhan anak usia 0-5 tahun. MGRS menghasilkan standar pertumbuhan normal (preskriptif) yang berbeda dengan deskriptif. Standar baru memperlihatkan bagaimana pertumbuhan anak dapat dicapai apabila memenuhi syarat-syarat tertentu, misalnya pemberian makan, imunisasi dan asuhan selama sakit. Standar dapat digunakan di seluruh dunia, karena penelitian menunjukkan bahwa anak-anak dari negara manapun akan tumbuh sama bila gizi, kesehatan dan kebutuhan asuhannya dipenuhi. (WHO \& Depkes, 2008:2). Lebih lanjut dikatakan bahwa standar baru ini juga bermanfaat karena: (1) standar baru menetapkan bayi disusui sebagai model pertumbuhan dan perkembangan bayi normal yang hasilnya kebijakan kesehatan dan dukungan publik untuk menyusui harus diperkuat; (2) standar baru lebih dini dan sensitif untuk mengidentifikasi anak pendek dan anak gemuk/ sangat gemuk; (3) standar baru seperti indeks massa tubuh (IMT) sangat berguna untuk mengukur peningkatan kejadian sangat gemuk; (4) grafik yang menunjukkan pola laju pertumbuhan yang diharapkan dari waktu ke waktu memungkinkan petugas kesehatan mengidentifikasi anak-anak yang berisiko menjadi kurang gizi atau gemuk sedini mungkin tanpa menunggu anak-anak menderita masalah gizi.

Salah satu teknik analisis untuk mengetahui hubungan antara berbagai variabel dalam kesehatan yakni analisis multilevel. Analisis multilevel merupakan analisis yang menggambarkan struktur multilevel dengan mempertimbangkan pengaruh struktur sosial pada keluaran

Modd Multiledd PetumbuhanAnak - 135 Irianton A ritonang 
individu. Posyandu menjadi struktur sosial yang dapat mempengaruhi pertumbuhan anak usia 0-24 bulan di lingkungan posyandu tersebut, yakni bagaimana pencapaian pertumbuhan anak 0-24 bulan dalam konteks posyandu. Kegiatan penimbangan dan penyuluhan gizi di posyandu setiap bulannya bagi seluruh ibu yang mempunyai anak 0-24 bulan dapat mempengaruhi kesehatan anak mereka. Konteks sosial kegiatan posyandu adalah sebagai upaya dari, oleh dan untuk masyarakat di tingkat dusun yang mencakup sekelompok anak usia 0-24 bulan) pada level 2, dan tingkat desa yang mencakup sekelompok dusun pada level 3. Sedangkan tanggungjawab pembinaannya posyandu dilakukan oleh petugas/tenaga kesehatan Puskesmas.

Analisis jalur memakai regresi dengan variabel antara, sehingga dapat diketahui pengaruh langsung dan tidak langsung dari variabel bebas terhadap variabel terikat. Teknik analisis ini sangat tepat untuk melakukan uji hipotesis hubungan kausal antar variabel yang disusun berdasarkan analisis logis, teori, pengalaman dan hasil penelitian yang relevan. D emikian pula analisis ini dapat mengetahui pengaruh masing-masing variabel atau mengetahui variabel bebas yang paling berpengaruh terhadap variabel bebas yang tercermin dalam koefisien jalur berupa koefisien regresi yang telah dibakukan.

Variabel yang dianggap paling mempengaruhi pertumbuhan anak usia 0-24 bulan pada model level 1, meliputi variabel langsung utama berupa karakteristik individu anak (berat badan lahir, seks dan stratifikasi usia) dan karakteristik ibu (status gizi). Kemudian variabel tidak langsung yang mempengaruhi pertumbuhan anak 0-24 bulan terdiri dari pengetahuan ibu tentang gizi seimbang dan variabel sikap ibu terhadap kegiatan posyandu. Model pada level 2, yakni disamping mencakup model pada level 1 juga dipertimbangkan program posyandu di tingkat dusun berdasarkan indikator: (1) hasil penimbangan atau tren status gizi (N/D), yakni proporsi anak yang naik berat badannya dibandingkan jumlah anak balita yang ditimbang di wilayah dusun; (2) keberhasilan program (N/S) yakni proporsi anak yang naik berat badannya dibandingkan dengan keseluruhan anak balita yang ada di wilayah dusun; (3) partisipasi masyarakat (D/S) yakni proporsi jumlah anak yang ditimbang

136 - Jumal PenditiandanEvaluas Penddikan E disi D ies Natalis ke-48 UNY 
dibandingkan dengan keseluruhan anak yang ada di wilayah dusun. Analisis dilanjutkan ke model level 3, yakni disamping mencakup variabel pada level 1 dan level 2, juga dipertimbangkan pada tingkat desa, khususnya berkaitan dengan hasil penimbangan (N/D) dan keberhasilan program (N/ S).

Berdasarkan kajian pertumbuhan anak 0-24 bulan melalui analisis model multilevel dan analisis jalur, dijelaskan berbagai variabel yang mempengaruhinya pada level individu, pada level dusun (posyandu) dan pada level desa. Dengan demikian akan diperoleh model multilevel pertumbuhan anak usia 0-24 bulan dan variabel yang mempengaruhinya, yang dapat menggambarkan secara lebih baik keadaan kesehatan anak usia 0-24 bulan dan upaya mengoptimalkannya di kabupaten Sleman.

\section{Metode Penelitian}

Penelitian noneksperimen desain korelasional dilakukan pada 272 anak usia 0-24 bulan yang diambil secara acak stratifikasi dari 21 dusun di dua kecamatan (Sleman dan Moyudan) yang ditentukan secara purposif. Konstrak pengetahuan gizi seimbang yang terdiri dari lima faktor dan sikap ibu terhadap layanan posyandu yang terdiri dari dua faktor diperoleh melalui uji validitas dan reliabilitas item penyusun instrumen dengan program SPSS-15 dan penampilan ICC dengan program R. Pertumbuhan anak diperoleh melalui penimbangan berat badan dan pengukuran panjang badan yang diolah menjadi skor $\mathrm{Z}$ indeks $\mathrm{BB} / \mathrm{U}, \mathrm{PB} / \mathrm{U}, \mathrm{BB} / \mathrm{PB}$ dan IMT/U dengan program WHO Antro-2005. Analisis multilevel pertumbuhan anak dilakukan dengan program Stata-10 dan analisis jalur dilakukan dengan program Amos-8.

\section{Hasil Penelitian dan Pembahasan}

Hasil penelitian menunjukkan bahwa pengetahuan ibu tentang gizi seimbang 13,6\% kurang, 51,8\% cukup dan 34,6\% baik, sedangkan sikap ibu tentang layanan posyandu $79 \%$ kurang, 13,6\% cukup dan hanya 7,4\% baik. Rata-rata skor $\mathrm{Z}$ indeks BB/ U, PB/ U, BB/ PB dan IMT/ U masingmasing $-0,5307,-0,4739,-0,3404$ dan $-0,3166$. Hasil penelitian dengan 
indeks berat badan menurut usia (BB/U) menunjukkan bahwa pertumbuhan (skor Z) anak-anak usia 0-24 bulan di wilayah penelitian masih lebih rendah dari standar WHO 2005 dan sebagian besar anak berstatus gizi baik. Meskipun demikian hasil penelitian menunjukkan bahwa nilai rata-rata skor Z anak laki-laki relatif lebih rendah dibanding anak perempuan. Hal ini bisa saja terjadi karena ada berbagai faktor yang berkaitan, misalnya pengasuhan anak yang menentukan kondisi kesehatan dan asupan gizi yang diterima anak, yang selanjutnya mempengaruhi pertumbuhannya. Dalam hal ini kondisi anak perempuan lebih baik dibanding anak laki-laki.

Pertumbuhan anak-anak usia 0-24 bulan berkorelasi positif dengan IMT ibu. Distribusi ibu menurut IMT menunjukkan bahwa sebagian besar ibu berstatus gizi baik, namun ditemukan juga yang berstatus gizi kurang dan berstaus gizi lebih masing-masing $13,6 \%$ dan 17,6\%. Hal ini menunjukkan adanya ketidakseimbangan gizi ibu, yang mana hal ini juga memperkuat pendapat bahwa terjadi masalah gizi ganda. Demikian pula hasil pengukuran lingkar lengan (lila) ibu, sebagian besar ibu (69,5\%) menderita kekurangan gizi atau kekurangan energi kronis (KEK) karena Lila mereka lebih rendah dari 23,5. Terjadinya masalah kekurangan gizi pada ibu-ibu juga didukung oleh rendahnya pengetahuan ibu tentang gizi seimbang. D emikian pula sebagian besar ibu memberikan tanggapan yang negatif terhadap kegiatan yang ada di posyandu. Padahal kehadiran posyandu di masyarakat diharapkan dapat meningkatkan pengetahuan dan status gizi ibu yang selanjutnya akan berpengaruh terhadap pertumbuhan dan status gizi anak-anak mereka. Fenomena sikap ibu yang kurang baik terhadap kegiatan posyandu mengundang pertanyaan apakah kegiatan posyandu yang ada selama ini hanya berjalan seadanya, monoton dan menjenuhkan serta ibu-ibu tidak merasa mendapat sesuatu dari kegiatan tersebut.

Posyandu diadakan sebagai kegiatan dari, oleh dan untuk masyarakat, dimaksudkan sebagai upaya pemberdayaan masyarakat untuk menolong dirinya sendiri dalam mencapai derajat kesehatan yang setinggi-tingginya. Namun kenyataan di lapangan menunjukkan hal yang berbeda, belum terjadi proses transfer pengetahuan dan ketrampilan, khususnya dalam 
upaya memperbaiki tingkat pertumbuhan anak 0-24 bulan. Hal ini tidak sesuai dengan apa yang disebutkan oleh Noeng Muhadjir (2000:94), bahwa demokratisasi yang hakiki ditunjukkan dengan tumbuh berkembangnya kemandirian pada tingkat gass rot. Kemandirian masyarakat/ keluarga dalam hal menolong dirinya untuk mencapai derajat kesehatan yang setinggi-tingginya belum terjadi, termasuk upaya mencapai pertumbuhan dan status gizi anak 0-24 bulan.

Pertumbuhan anak usia 0-24 bulan pada penelitian ini juga berhubungan dengan berat badan saat lahir dan seks anak. Hal ini dijuga diperkuat oleh adanya perbedaan pertumbuhan anak menurut stratifikasi usia. Pertumbuhan anak usia 0-6 bulan berbeda dengan pertumbuhan anak usia di atas satu tahun, yang mana kondisi anak usia 7-12 bulan merupakan transisi kedua kelompok tersebut. Ada kecendenungan semakin tua usia anak, pertumbuhannya semakin tidak baik. Sama halnya dengan yang diungkapkan oleh Minarto (2006) yang menemukan bahwa bayi 6-12 bulan mengalami dua bentuk gangguan pertumbuhan yang serius, yakni penurunan kecepatan pertumbuhan panjang badan antara usia 6-12 bulan, dan gangguan penurunan berat badan yang serius lebih besar dibanding penurunan panjang badan. Lebih lanjut dikatakan bahwa frekuensi dan kontinuitas berat badan tidak naik secara konsisten berpengaruh terhadap pertumbuhan bayi. Semakin sering berat badan tidak naik, kenaikan berat badan bayi 6-12 bulan dan berat badan bayi 12 bulan semakin rendah.

Atmarita, et al. berdasarkan analisis data Susenas 1989-2005 juga sependapat dengan temuan Minarto, status gizi anak Indonesia tidak berubah secara bermakna. Kajian terhadap faktor yang mempengaruhi penyebab pertumbuhan dan status gizi anak-anak adalah pola pemberian makanan anak, baik kuantitas maupun kualitasnya, rendahnya cakupan ASI eksklusif yang berperan terhadap gagal tumbuh pada bulan ke-4 hingga ke18, makanan pendamping telah diperkenalkan terlalu dini, infeksi penyakit dan rendahnya konsumsi makanan padat energi (Atmarita et.al., 2005). D emikian pula frekuensi berat badan tidak naik dan berat badan bayi usia 12 bulan ditentukan oleh berat badan bayi 6 bulan, pola makanan bayi, lama bayi menderita batuk (Minarto, 2006). Keadaan pertumbuhan anak usia 0-24 di wilayah penelitian juga mempengaruhi hasil penimbangan

Modd Multiledd PetumbuhanAnak - 139 
(N/D ) pada tingkat dusun yang selanjutnya mempengaruhi hasil program (N/S) tingkat desa. Hal ini hendaknya menjadi bahan pertimbangan pelaksana program, karena pertumbuhan anak usia 0-24 bulan bukan saja berhubungan dengan faktor individu anak, tetapi juga ikut mempenganuhi kondisi pertumbuhan anak-anak dalam wilayah dusun dan desa.

Revitalisasi posyandu dikatakan berhasil apabila dapat mengembalikan fungsi utamanya sebagai lembaga masyarakat, terutama masyarakat desa untuk memantau pertumbuhan anak. Kegiatan pendidikan dan pelatihan pada ibu-ibu bagaimana menimbang dan mencatat di KMS pertumbuhan berat badan anak serta dapat mengartikan KMS dengan baik, merupakan kunci keberhasilan revitalisasi posyandu. Kegiatan penimbangan diutamakan pada anak 0-24 bulan sesuai dengan perkembangan masalah yang diketahui dari hasil penelitian mutakhir. Tolok ukur lain keberhasilan revitalisasi posyandu ialah mengkoreksi kesalahan para petugas gizi dan kesehatan yang selama ini dilakukan yang menggunakan KMS sebagai catatan status gizi. Konsep penyimpangan pertambahan dari batas normal atau gouth faltering sudah waktunya diajarkan dan dilatihkan kepada petugas gizi dan kesehatan serta kader. Kegiatan posyandu yang belum optimal ini juga didukung oleh penelitian Ellis Endang Nikmawati, et al. (2010) di kabupaten Bogor yang mengungkapkan bahwa pelaksanaan program gizi dan kesehatan di posyandu, pelaksanaan KIE, pelayanan kesehatan belum berjalan dengan baik karena terkendala tempat, SD M, media dan alat-alat yang masih belum memadai. Program perbaikan gizi masyarakat sebagai kebijakan nasional telah ditetapkan sebagai salah satu program dalam upaya mencapai tujuan MilleniumDeudqpment Gcals (MD G s) tahun 2015, khususnya dalam rangka menurunkan angka kematian bayi di Indonesia. Kegagalan untuk mencapai pertumbuhan anak usia 0-24 bulan juga dapat berakibat tidak tercapainya tujuan tersebut. 


\section{Kesimpulan}

Berdasarkan hasil penelitian, dapat disimpulkan bahwa:

1. Model pertumbuhan anak usia 0-24 bulan pada level 1 menunjukkan ada pengaruh variabel berat badan lahir, seks dan stratatifikasi usia anak dan status gizi ibu (IMT). Meskipun variabel pengetahuan ibu tentang gizi seimbang dan variabel sikap ibu terhadap kegiatan posyandu secara statistik tidak berpengaruh, namun secara substansi tetap dipertimbangkan karena pencapaiannya masih rendah.

2. Model pertumbuhan anak 0-24 bulan pada level 2 (tingkat dusun) mengikutsertakan pengaruh variabel hasil penimbangan (tren status gizi), sebaliknya dengan variabel partisipasi masyarakat dan pencapaian program berpengaruh tidak signifikan.

3. Model pertumbuhan anak 0-24 pada level 3 (tingkat desa) tidak ditemukan pengaruh variabel hasil penimbangan (tren status gizi) dan variabel pencapaian program.

4. Model analisis jalur yang mempengaruhi pertumbuhan anak 0-24 bulan, yakni obseved variabel endogenas yang terdiri dari status gizi ibu (IMT), pengetahuan ibu tentang gizi seimbang, pertumbuhan anak indeks $\mathrm{BB} / \mathrm{U}$, dan hasil penimbangan (tren status gizi) pada tingkat dusun serta pencapaian program tingkat desa. Sedangkan doseved variabel exogenousterdiri dari sikap ibu terhadap posyandu, berat badan lahir, seks dan stratifikasi usia anak.

\section{Daftar Pustaka}

Atmarita, et al. (2005). Status gizi anak Indonesia 1989-2005 dan faktor risiko terpenting, Jumal Gizi Indonesia, 28 (2), 61-68

D epkes. (2005). Rencana aksi masional (RAN) pencegahan dan penanggulangan gंzi bunk 2005-2009. Jakarta: D epkes RI . (2008). Riset keshatan dasar 2007. Jakarta: Badan Litbang. 
De Onis, M. et al. (2004). WHO multicentre growth reference study (MG RS): Rationale, planning and implementation. Food Nutr. Bull,25 (Suppl 1), 81-89.

D inkes Sleman. (2007). Profil keshatan kabupaten Sleman 2007.

Ellis Endang Nikmawati, et al. (2010). Gap analisis program gizi dan kesehatan di posyandu kabupaten Bogor. Jumal Pancgndan Gizi IPB.

G riffiths M., Dickin K., \& Favin M. (1996). Promoting the gronth of dildren: What work. Rationale and guicance for progams Human D evelopment D epartment. The World Bank.

Minarto. (2006). Pengaruh berat badan tidak naik terhadap pertumbuhan pada bayi 6-12 bulan di kabupaten Bogor. Jumal Gizi Indanesa, 29 (2), 89-100.

Noeng Muhadjir. (2000). Kebjakan dan peetenanaan sosial. Yogyakarta: Penerbit Rake Sarasin.

Soekiman. (2000). Pelu paradigra banu unthk menangyilang masalah ġzi makro d Indonesia Diambil pada tanggal 12 Juli 2007, dari Web: www.gizinet

Soetjiningsih. (1995). Tumbuhkenbanganak. Jakarta: EGC.

WHO \& Depkes. (2008). Modul pdatihan perilaian petumbuhan anak. Jakarta: WHO \& D epkes RI.

142 - Jumal PenditiandanEvaluas Penddikan E disi D ies Natalis ke-48 UNY 